\title{
GENDER EQUALITY AND CORPORATE GOVERNANCE IN SLOVAKIA
}

\author{
Hussam Musa, Lenka Debnárová, Zdenka Musová, \\ Peter Krištofík
}

\section{Introduction}

In the European environment, a major initiative for responsible business practice was introduced in the Lisbon summit in March 2000, which EU leaders agreed to make the European Union the most competitive and dynamic knowledgebased economy in the world, capable of sustained economic growth with more jobs and grater social cohesion by 2010 (Musová \& Poliačiková, 2008). Consequently, the European Commission issued several documents on social responsibility of businesses in order to help integrate the concept of corporate social responsibility (CSR) into everyday business life. In the year 2001 the European Commission in its Green Paper published the first official definition of CSR as the "voluntary integration of social and environmental concerns of company's commercial operations and its relationship with its stakeholders" (Horehájová \& Marasová, 2008; Sopková \& Raškovská, 2012; Martinčík \& Polívka, 2012).

The global economic and financial crisis has considerably slowed down the implementation of the objectives of the Green Paper and significantly deepened mistrust from customers, shareholders, investors, employees and the public. The crisis has exposed fundamental issues and unsustainable trends in Europe, which can't be ignored. The European Commission created a strategy for Europe, in 2020, to emerge from the crisis and prepare the EU economy for the next period. This strategy has identified three key drivers for growth, which are to be implemented through concrete actions at both the EU and national level (European Commission [EC], 2010):

- smart growth (through more effective investments in education, research and innovation),

- sustainable growth (support for a competitive low-carbon economy with effective use of resources),
- and inclusive growth (support for the economy with high employment, social and territorial cohesion, and poverty reduction).

The present century is one where the nature of business is changing. Markets, customers, competitors and technology are all in flux, thus if companies want to be successful, they must also change their practices (Adamska \& Minárová, 2014). Responsibility in business again comes to the fore and in the current post-crisis period is one of the factors that can significantly contribute to the achievement of stability and sustainable growth on a global level. Business should build its position on the principles of transparency and an integrated approach to sustainable products and services, and the active cooperation of all stakeholders to contribute to the overall well-being of society as well as the entire planet.

This paper will firstly focus on the economic area of corporate social responsibility. In this economic area, corporate governance plays an important role, particularly in relation to shareholders and employees. The next part is related to gender equality and presents a systematic procedure to integrate the needs and priorities of women and men in all policies and measures promoting equality while taking into account their mutual differences and interests. From this theoretical background, we present our research results, which test whether there is a relation between the level of corporate governance and the representation of women on company boards.

\section{Corporate Governance as a Tool of Corporate Social Responsibility}

Corporate Social Responsibility was described by Carroll (1999) as follows: the social responsibility of business encompassing the economic, legal, ethical and discretionary expectations that society has of organizations at 
a given point in time. Liebman (in Mallin (2013)) noted, at present, the notion of Corporate Social Responsibility has narrowed down to a mere issue of corporate governance. In the context of the current issues, corporate governance is one of the key elements in building well-governed companies into the single European market. Well-functioning and sustainable companies can contribute to sustainable growth, which is one of the three priorities set out in the Europe 2020 Strategy.

The development of corporate governance has been articulated by theories from a number of disciplines, including finance, economics, accounting, law, management, and organizational behavior. The main theory is the agency theory that identifies the relationship between one party (the principal) who delegates work to another party (the agent). In context of a corporation, the owners are the principal and the directors are the agents. Sir Adrian Cadbury (1992) first defined the concept of corporate governance as "the system by which companies are directed and controlled". Corporate governance ensures a balance between economic, social, individual and municipal goals of the company with respect to all stakeholders. A definition from the OECD clearly captures the essence of corporate governance as "the system by which business corporations are directed and controlled. The corporate governance structure specifies the distribution of rights and responsibilities among different participants in the corporation, such as the board, managers, shareholders and other stakeholders and spells out the rules and procedures for making decisions in corporate affairs" (OECD, 2004). The OECD Principles of Corporate Governance are divided into the following areas: ensuring the basic for effective corporate governance framework, the rights of shareholders and key ownership functions, the equitable treatment of shareholders, the role of stakeholders in corporate governance, disclosure and transparency, and the responsibilities of the board. OECD Principles became the basis for the creation of national codes of corporate governance in most countries of the world, including Slovakia. The OECD has started a review process of principles and will issue new ones in 2015, which confirms the growing importance of corporate governance. Subsequently Central European Corporate Governance Association - CECGA will also revise the Slovak Code.

\section{Gender Diversity in the Context of Corporate Governance}

One of the principles of corporate governance, the responsibilities of the board, is closely related to the issue of gender equality. According to this principle the board should ensure the strategic management of the company, the effective monitoring of management and should act responsibly towards both society and shareholders. These activities may be determined by many factors and one of them is gender equality.

Discussions on gender equality are conducted within the issues of diversity management. The basis of the diversity management concept can be seen in the natural societal mix with people of different age, gender, race, ethnicity, mental and physical abilities, sexual orientation and other characteristics (Eger \& Indruchová, 2014). Hubbard (2004) defines diversity management as "a process of planning for, organizing, directing and supporting these collective mixtures in a way that adds measurable difference to organizational performance".

In the Slovak environment, women are seen as part of the company, but unfortunately, with fewer opportunities for self-realization in comparison with men, a reflection found in gender statistics. Institutions that should take care of most balanced gender representation are also seen as less inclined equalization of both sexes. Thus, there is a situation where the company maintains gender inequality, first by the public authorities, but also the company itself (Bútorová, 2009).

Gender equality is a fundamental right guaranteed by Article 23 of the Charter of Fundamental Rights of the European Union. Similarly, Article 3 of the Treaty on the Functioning of the European Union proclaims that, the European Union focuses on the elimination of inequalities and supports a balance between men and women in all its activities. The European Commission reaffirmed its commitment to gender equality by the creation of the Women's Charter and the Strategy of equality between women and men (2010-2015). Achieving gender equality is also important for the EU's growth, employment and social cohesion. The already noted Strategy 2020 contains the main objective of increasing the employment rate of women and men (20-64 years old) to $75 \%$ in 2020 . Women's 
employment should increase both quantitatively and qualitatively. Female employment rate in the EU-28 was $63.5 \%$ for 2014.

Given the greater participation of women in the labor market and education, we would expect a corresponding improvement in terms of the effective use of women's talents. Statistics of the European Commission show that the proportion of women on the boards of the largest listed companies in the EU was $17.8 \%$ in October 2013. Moreover, there are very few women in the most influential positions: just $4.8 \%$ of the chairpersons of these companies and only $2.8 \%$ of CEOs are women (EC, 2014a). There are also significant differences in the representation of women on the boards of large publicly-listed companies in the EU. For example, in Finland, boards were $30 \%$ female, but in Malta the figure was just over $2 \%$. The best five performing countries were: Finland $(30 \%)$, France $(30 \%)$, Latvia $(29 \%)$, Sweden $(26 \%)$ and the Netherlands (25\%). A positive point was that Slovakia was ranked in the $6^{\text {th }}$ place just behind the Netherlands with $24 \%$. But there are still Member States where men still hold more than $90 \%$ of board positions (Malta, Cyprus, Estonia, Greece, Romania and Portugal). Nevertheless, there has been significant progress over the last decade thanks to the intense debate and regulatory pressure (EC, 2014b).

Effective use of human capital is one of the ways to improve European competitiveness. The European Commission argues that a more balanced representation of women and men in economic decision-making positions can contribute to a more productive and innovative working environment and improved company performance. The European Commission claims that the progress in gender equality can have the following positive impacts (EC, 2012):
- improved company
performance:

companies with a higher share of women at top levels can deliver strong organizational and financial performance,

- better quality of decision-making: a more diverse board of directors can contribute to better performance because decisions are based on evaluating more alternatives,

- improved corporate governance and ethics: the quality of corporate governance and ethical behavior can be higher in companies with a high share of women on boards,
- better use of the talent pool: $60 \%$ of university graduates in Europe are women. Systematically including suitable candidates of both sexes ensures that new board members are selected from the very best candidates, both male and female.

For a thorough understanding of the issue, we have reviewed related studies to see if they confirm that gender diversity has a positive effect on a firm's value, and the greater gender diversity affects the larger economic gains. These findings were confirmed by the Cai et al. (2006) on a sample of 114 companies listed on the London Stock Exchange. Adams and Ferreira (2009) found evidence for an argument about corporate board diversity, namely that women pay greater attention to monitoring firms; women board members have better attendance records; their presence improves the attendance of men; and women were more involved in monitoring committees in U.S. firms during the period 1996-2003. The authors also examined whether gender diversity impacts corporate performance (Tobin's $g$ and ROA). They found that diversity has a positive impact on performance in firms that, otherwise, have weak governance, as measured by their abilities to resist takeovers. But enforcing gender quotas in the boards could ultimately decrease shareholder value in firms with strong governance. Their explanation is that greater gender diversity could lead to over monitoring in those firms. Other authors, Srinidhi, Gul and Tsui (2011) confirmed the hypothesis that the U.S. corporations with gender diverse boards exhibit higher-quality earning. Their sample period was 2001-2007. They also claimed that firms with female directors, specifically in the audit committee, exhibit better reporting discipline by managers.

But other studies did not confirm the positive impact of women on corporate boards. For example Álvarez et al. (2010), show that companies with higher levels of gender diversity do not obviously outperform companies with lower levels of diversity. The proportion of female directors on the board is associated with a positive and significant impact on Tobin's $Q$, but no significant effects on the other variables were detected (ROA, ROE, ROS, ROA - net). The presence of female directors on boards has a mainly non-significant effect on corporate performance. The sample was with Spanish 
companies that were listed on the Madrid Stock Exchange over the period 2004-2006.

In another study, Elbadry (2010) examined the hypothesis of a positive impact of women on the board of directors to mitigate information asymmetry in non-financial UK companies listed in the London Stock Exchange from 2003 to 2006. The study showed that the existence of women on the board had no effect on the degree of asymmetric information. Moreover, only 102 companies out of 392 companies in the sample had women on their boards. Furthermore the study showed that the higher the quality of corporate governance, the lower the degree of asymmetric information, and vice versa. So given this relationship between the corporate governance and information asymmetry, the implication was that there was no relationship between representation of women on the board and the quality of corporate governance.

Some studies have researched this issue in terms of psychology. On the positive side, gender and racial diversity may operate as occupational diversity does in small groups, enabling them to come to better decisions and to come to them more quickly. On the negative side, gender and racial diversity have been found to increase conflict in small groups, and this may inhibit their decision-making capacity (Dobbin \& Jung, 2011).

The results of these studies indicate that women on the boards may affect the level of corporate performance, firm value, monitoring committee activities, decision making, risk taking and information asymmetry. In the next section, we will examine whether there is a relationship between the gender equality and the level of corporate governance in Slovakia.

\section{Main Characteristics of the Research and the Results of Correlation Analysis}

To the best of our knowledge, this is the first paper to investigate the link between corporate governance and gender equality in companies on the Bratislava Stock Exchange. Studies in this area are not available even in neighboring countries such as Czech Republic, Hungary and Poland. Our main motivation was the highly topical issue of gender equality and corporate governance in the European Union.

In the first part of our analysis we conducted an extensive survey of disclosure in corporate governance by companies whose securities are listed on the Bratislava Stock Exchange. The second part was to create our corporate governance index for each monitored company. In the final stage, we identified the existence of dependence between the representation of women on boards and the level of corporate governance based on correlation analysis.

The subject of our research was all companies whose securities are listed on the Bratislava Stock Exchange between the period 2011-2013. The aim of our research is to determine whether a relationship exists between the representation of women on the boards and the level of corporate governance in companies listed on the Bratislava Stock Exchange. There were 104 companies in 2011, 109 in 2012 and 102 companies in 2013. The number of companies which quotes their shares and bonds is in the following table (Tab. 1).

We obtained the information from the companies' annual financial reports which are available in the Central Register of Regulated Information, the Register of Financial Statements and on the companies' websites for period 2011-2013.

Tab. 1: The number of shares issuers and bonds issuers for the period 2011-2013

\begin{tabular}{l|r|r|r} 
& $\mathbf{2 0 1 1}$ & $\mathbf{2 0 1 2}$ & $\mathbf{2 0 1 3}$ \\
\hline The number of shares issuers & 87 & 92 & 84 \\
\hline The number of bonds issuers & 11 & 11 & 11 \\
\hline The number of issuers of shares and also bonds & 6 & 6 & 7 \\
\hline TOTAL number of issuers & 104 & 109 & 102 \\
\hline
\end{tabular}


We measured the level of corporate governance using our corporate governance index. This index uses ordinal measures of various evaluative criteria (see Annex). The criteria were as follows:

a) disclosure of the current annual report in the Central Register of regulated Information CERI,

b) disclosure of the current annual report in the Register of Financial Statements RUZ,

c) disclosure of the current annual report on the companies' websites,

d) the scope and clarity of the information about corporate governance in annual report according to $\S 20$ of the Accounting Act,

e) the scope, clarity and quality of information in corporate governance statement,

f) information about board members, such as names, experience, responsibility and functions,

g) information about the structure and amount of remuneration for individual members of the board,

h) information about risk management, defined predictable risks and risk quantification,

i) information about the establishment and activities of an Audit Committee, or the failure to establish one,

j) information about the establishment and activities of a Remuneration Committee, or the failure to establish one,

k) information about the establishment and activities of a Nomination Committee, or the failure to establish one.

Assessment methods together with the results are in the annex of this paper. Selection criteria evaluation was conducted based on the results of a survey concerning disclosure of corporate governance and based on the inspiration mentioned in foreign studies. We assign weights to each assessment criterion in corporate governance index with the aim to objectively assess the importance of each criterion. Our corporate governance index was as follows:

$$
\begin{aligned}
& \text { CG index }=0.095 *(a+b+c)+ \\
& +0.079 * d+0.159 * e+0.079 * f+ \\
& +0.079 * g+0.079 * h+0.079 * i+ \\
& +0.079 * j+0.079 * k
\end{aligned}
$$

Individual assessment criteria were given a score and assigned a weight according to their degree of importance. We set the value of coefficients based on expert estimation and supported by Saaty's method of determining the weights. The expert group consisted of people on boards from Central European Corporate Governance Association that has dealt with issues of corporate governance in Slovakia since 2004. We identified through expert estimation that the criterion ("the scope, clarity and quality of information in corporate governance statement") to be the most important one in the index. Other important criteria with the lower value of the coefficient were: "disclosure of the current annual report in CERI", "disclosure of the current annual report in RUZ" and "disclosure of the current annual report on the companies' websites". Other criteria were the same coefficients with respect to their significance in comparison with the aforementioned higher ranked criteria in the index. Subsequently, we compiled an order of the companies based on corporate governance index with expert estimation of weights with Saaty's weights method. The order of the companies was the same in both causes for the whole period. For purposes of analysis, we decided to use the corporate governance index, which weights were based on expert estimation. Each monitored company was scored using a weighted sum of the evaluated criteria. This allowed corporate governance comparisons across companies.

After intensive data collection for each monitored company we evaluated the data in the statistical program SPSS 18 through the Spearman's rank correlation coefficient. The Spearman's rank correlation coefficient was used because normal distribution of statistical values was not confirmed.

Spearman's rank correlation coefficient

$$
R S=\frac{1-\left(6 \sum_{i=1}^{n} d_{i}^{2}\right)}{n \times\left(n^{2}-1\right)}
$$

where: $d_{i}$ is the difference between the rank character $\mathrm{x}, \mathrm{y}$ and $\mathrm{n}$ is the range of random selection. The coefficient can have values in the range $<-1 ; 1>$. If the value is closer to the -1 or to the 1 , the dependence is tighter. The positive coefficient confirms direct dependence and negative indirect relationship between the monitored characteristics. 
From the available annual reports and Business Register of the Slovak Republic, we collected data about female representation on the boards of companies. The gender equality was measured by the percentage of women on the board of directors and supervisory board 2011-2013.

Based on results of the studies reviewed above and our assumptions, we set the following hypothesis.

$\mathrm{H}$ : There is a correlation between the representation of women on the boards and the level of corporate governance in companies listed on the Bratislava Stock Exchange.

We evaluated the level of corporate governance using the corporate governance index. Table 2 gives the basic characteristics of this index for the period 2011-2013. The Corporate governance index reached a minimum value at 0 and a maximum of 1.38 for the whole reporting period. Companies achieved an average value of the index of around 0.5 point. Standard deviation of the mean had a growing tendency, from 0.38 to 0.42 points. Distribution asymmetry is evident from the value of skewness and kurtosis parameters. A positive value of skewness indicates to us that the mean is greater than the median - most of the values of the index are lower than the mean. We found out that there were higher proportions of companies with below-average value of corporate governance index. Approximately $20 \%$ of companies in each reference year did not disclose information in the right form or information was not disclosed at all. Therefore, we could not prepare the corporate governance index for these companies. Based on the negative values of the kurtosis a platykurtic distribution was confirmed a. We can conclude that the incidence of extreme value is less frequent compared to the normal distribution for the period 2011-2013.

Tab. 2: Descriptive statistics of corporate governance index for period 2011-2013

\begin{tabular}{l|c|c|c|c|r|r|r|r|r|r|r} 
& \multirow{2}{*}{$\mathbf{N}$} & Min & Max & Median & Modus & Mean & $\begin{array}{c}\text { Std. } \\
\text { Deviation }\end{array}$ & Stat. & $\begin{array}{c}\text { Std. } \\
\text { Error }\end{array}$ & Stat. & $\begin{array}{c}\text { Std. } \\
\text { Error }\end{array}$ \\
\hline $\begin{array}{l}\text { CG Index } \\
2011\end{array}$ & 104 & .00 & 1.38 & 0.4275 & 0.00 & 0.4847 & 0.38007 & 0.405 & 0.237 & -.738 & .469 \\
\hline $\begin{array}{l}\text { CG Index } \\
2012\end{array}$ & 109 & .00 & 1.38 & 0.4270 & 0.00 & 0.5094 & 0.39455 & 0.332 & 0.231 & -.838 & .459 \\
\hline $\begin{array}{l}\text { CG Index } \\
2013\end{array}$ & 102 & .00 & 1.38 & 0.4270 & 0.00 & 0.5072 & 0.42421 & 0.420 & 0.239 & -1.01 & .474 \\
\hline
\end{tabular}

Source: own

The following table (Tab. 3) presents the descriptive statistics representation of women in the total number of directors and the supervisory board for the 2011-2013 timeframe. We found significance in the rising median value, which was in $17 \%$ in 2011 and $22 \%$ in 2013. The average representation of women increased year on year 2012/2013 from 23\% to $24 \%$, while the average in the EU-28 was lower at $18 \%$. Some companies did not have any woman on the board or the supervisory board. The number of these companies increased from 24 in 2011 to 29 in 2012 and subsequently decreased to 26 companies in 2013. Women on the board of directors were not represented in 65 companies in 2011 and 2013 and in 70 companies in 2012. The number of these companies was twice more compared with companies without the representation of women on the supervisory boards. The number of companies which did not have representation of women on the supervisory board was 36,38 and 32 companies for the period 2011-2013. The average number of women on boards of directors was around 0.44 and average number of women on supervisory board oscillated by one. Women were represented on the supervisory boards more frequently than on boards of directors. 
Tab. 3: Descriptive statistics of women on board for period 2011-2013

\begin{tabular}{|c|c|c|c|c|c|c|c|c|c|c|c|}
\hline & \multirow[b]{2}{*}{$\mathbf{N}$} & \multirow[b]{2}{*}{ Min } & \multirow[b]{2}{*}{ Max } & \multirow[b]{2}{*}{ Median } & \multirow[b]{2}{*}{ Modus } & \multirow[b]{2}{*}{ Mean } & \multirow{2}{*}{$\begin{array}{c}\text { Std. } \\
\text { Deviation }\end{array}$} & \multicolumn{2}{|c|}{ Skewness } & \multicolumn{2}{|c|}{ Kurtosis } \\
\hline & & & & & & & & Stat. & $\begin{array}{l}\text { Std. } \\
\text { Error }\end{array}$ & Stat. & $\begin{array}{l}\text { Std. } \\
\text { Error }\end{array}$ \\
\hline $\begin{array}{l}\text { Women } \\
\text { Board } \\
2011\end{array}$ & 104 & .00 & 0.83 & 0.1667 & 0.00 & 0.2295 & 0.20006 & 0.782 & 0.237 & .064 & .469 \\
\hline $\begin{array}{l}\text { Women } \\
\text { Board } \\
2012\end{array}$ & 109 & .00 & 1.00 & 0.2000 & 0.00 & 0.2328 & 0.20992 & 0.857 & 0.231 & .714 & .459 \\
\hline $\begin{array}{l}\text { Women } \\
\text { Board } \\
2013\end{array}$ & 102 & .00 & 1.00 & 0.2222 & 0.00 & 0.2390 & 0.21034 & 0.862 & 0.239 & .822 & .474 \\
\hline
\end{tabular}

Source: own

\section{Tab. 4: Correlation analysis for period 2011-2013}

\begin{tabular}{l|c|c|c}
\multicolumn{2}{l|}{ Spearman's rho } & CG index & Sig. \\
\hline \multirow{2}{*}{ Female Board } & 2011 & -0.175 & $0.075^{\star *}$ \\
\cline { 2 - 4 } & 2012 & -0.303 & $0.001^{*}$ \\
\cline { 2 - 4 } & 2013 & -0.236 & $0.017^{*}$ \\
\hline
\end{tabular}

${ }^{*}$ Correlation is significant at the 0.05 level (2-tailed)

Source: own

${ }^{* *}$ Correlation is significant at the 0.1 level (2-tailed)

We examined a relationship between the representation of women on the board and the level of corporate governance by Spearman correlation coefficients. However the results differ significantly from those stated in the previous section of this paper. Values of Spearman's correlation coefficient are found in the following table (Tab. 4).

At the $5 \%$ significance level, we accepted the hypothesis about the existence of correlation between the representation of women on the boards and the level of corporate governance in companies listed on the Bratislava Stock Exchange for 2012 and 2013. We can also confirm the hypothesis for the 2011 period, but due to a higher $p$-value, the correlation is significant at the 0.1 level. The Spearman correlation coefficients were negative values. In this case, the higher proportion of women on the board of companies related to lower level of corporate governance. The values of correlation coefficients confirmed weak indirect dependence.

\section{Conclusions}

Gender equality is becoming increasingly important, especially because of European Union pressure. The European Commission has decided to take legislative action with the strong support of a number of member states. On 14 November 2012, it put forward a proposal for a Directive on improving the gender balance among non-executive directors of companies listed on the stock exchange. The European Parliament has repeatedly called upon companies and member states to increase female representation on company boards, and has invited the Commission to propose legislative quotas to achieve 30\% female membership of management bodies by 2015 and $40 \%$ by 2020 . Some member states have developed national legislation and other member states have self-regulatory initiatives.

By reviewing the literature, we find that there is a clear gap in examining the relationship between the representation of women on the 
board and the level of corporate governance. To the best of our knowledge, this is the first paper that examines the relationship between corporate governance and female on boards using data of companies on the Bratislava Stock Exchange. Similarly, we did not find comparable studies examining the relationship between the representation of women on boards and the level of corporate governance in comparable countries. We examined the existence of a relationship in two stages. In the first stage, we compiled a corporate governance index for each monitored company that allows us to determine the level of corporate governance. The data for the corporate governance index have been collected from the companies' annual reports and from their websites. In the second stage, we obtained information about the proportion of women on boards from the companies' annual reports and examined its effect on corporate governance. The main contribution of this paper is confirmation of the correlation between the representation of women on the board and the level of corporate governance for period 2011-2013. We confirmed the hypothesis of a correlation between the representation of women on the boards and the level of corporate governance in companies listed on the Bratislava Stock Exchange. The findings of the negative correlation were unexpected. On the negative correlation may affect a relatively short history of the capital market in Slovakia, a small number of active companies on the Stock Exchange in Bratislava and other factors that could be the subject of further research.

Hence, the outcome of this study could be used as the basis for future research. The main limitation of this paper is that the paper focused on the companies on the Bratislava Stock Exchange. Future work could extend the research by using the companies on over the counter market or the companies in other countries such as the Czech Republic. Next, we recommend the assembly of a regression model to examine the relationship between corporate governance and representation of women on boards with respect also other variables such as board size.

Finally, we believe that the findings of this research provide useful evidence of the level of corporate governance in Slovakia, a subject matter that has been covered in the previous research in corporate governance. This adds a new dimension to the studies in the corporate governance area and gender equality.

\section{References}

Adams, R., \& Ferreira, D. (2009). Women in the boardroom and their impact on governance and performance. Journal of Financial Economics, 94(2), 291-309. doi:10.1016/j.jineco.2008.10.007.

Adamska, M., \& Minárová, M. (2014). Role of Learning Organization in Building consumer Confidence. E\&M Ekonomie a Management, 17(1), 62-72. doi:10.15240/tul/001/2014-1-005.

Álvarez, I., Sanchez, I., \& Dominguez, L. (2010). The influence of gender diversity on corporate performance. Revista de Contabilidad - Spanish Accounting Review, 13(1), 53-88. doi:10.1016/S1138-4891(10)70012-1.

Bútorová, Z. (2009). Ona a on na Slovensku: Zaostrené na rod a vek. Bratislava: Inštitút pre verejné otázky. Retrieved October 19, 2014, from http://www.socialnapolitika.eu/index. php/7-rodova-rovnost-a-rovnost-prilezitosti/.

Cadbury, A. (1992). Cadbury Codex: The Financial Aspects of Corporate Governance. Retrieved October 20, 2013, from http://www. ecgi.org/codes/documents/cadbury.pdf.

Cai, C. X., Keasez, K., \& Short, H. (2006). Corporate Governance and Information Efficiency in Security Markets. European Financial Management, 12(5), 763-787. doi:10.1111/j.1468-036X.2006.00276.x.

Carroll, A. B. (1999). Corporate Social Responsibility. Evolution of a Definitional Construct. Business \& Society, 38(3), 268-295. doi:10.1177/000765039903800303.

Dobbin, F., \& Jung, J. (2011). Corporate board gender diversity and stock performance: The competence gap or institutional investor bias? Cambridge: Harvard University. Retrieved October 11, 2014, from http://scholar.harvard. edu/files/dobbin/files/2011_nclr_dobbin_jung.pdf.

Eger, L., \& Indruchová, Z. (2014). Diversity Management - Perceptions and Attitudes by Czech Managers. E\&M Ekonomie a Management, 17(1), 73-81. doi:10.15240/ tul/001/2014-1-006.

Elbadry, A. (2010). Corporate Governance and Asymmetric Information. Saarbrucken: VDM Verlag Dr. Muller GmbH \& Co.

European Commission. (2010). EURÓPA 2020. Stratégia na zabezpečenie inteligentného, udržatel'ného a inkuzívneho rastu. Brussels: European Commission. Retrieved September 18, 2014, from http://eur-lex.europa.eu/LexUriServ/ LexUriServ.do?uri=COM:2010:2020:FIN:SK:PDF.

European Commission. (2012). Women in economic decision-making in the EU: Progress 
report. Brussels: European Commission. Retrieved September 20, 2014, from http:// ec.europa.eu/justice/gender-equality/files/ women-on-boards_en.pdf.

European Commission. (2014a). Report on Progress on equality between women and men in 2013. A Europe 2020 initiative. Brussels: European Commission. Retrieved September 9, 2014, from http://ec.europa.eu/justice/ gender-equality/files/swd_2014_142_en.pdf.

European Commission. (2014b). Boosting equality between women and men in the EU. Key actions and figures. Brussels: European Commission. Retrieved September 9, 2014, from http://ec.europa.eu/justice/gender-equality/ files/documents/140303_factsheet_progress_en.pdf.

Horehájová, M., \& Marasová, J. (2008). The Institutional Factors of the Corporate Social Responsibility Development in the Central European. E\&M Ekonomie a Management, 11(2), 58-64.

Hubbard, E. E. (2004). Diversity Management. Amherst: HRD Press.

Mallin, C. (2013). Corporate Governance. Oxford: Oxford University Press.

Martinčík, D., \& Polívka, M. (2012). Contribution of Corporate Social Responsibility to the Shareholder Value: Experimental Perspective. E\&M Ekonomie a Management, 15(3),108-124.

Musová, Z., \& Poliačiková, E. (2008). Spoločenská zodpovednost' ako významný nástroj firemnej politiky. In M. Orviská, \& P. Pisár (Eds.), Lisabonská stratégia pre rast a zamestnanost'. Zborník príspevkov z medzinárodnej vedeckej konferencie (pp. 1-7). Banská Bystrica: Univerzita Mateja Bela, Ekonomická fakulta.
OECD. (2004). OECD Principles of Corporate Governance. Paris: OECD Publications Service. Retrieved May 20, 2014, from http://www.oecd.org/daf/corporateaffairs/ corporategovernanceprinciples/31557724.pdf.

Sopková, E., \& Raškovská, K. (2012). The Implementation of the Concept of corporate Social Responsibility in the Area of Income Tax in the Slovak Republic. E\&M Ekonomie a Management, 15(2),125-140.

Srinidhi, B., Gul, F., \& Tsui, J. (2011). Female Directors and Earnings Quality. Contemporary Accounting Research, 28(5), 1610-1644.

doc. Ing. Hussam Musa, PhD. Matej Bel Univesity in Banská Bystrica Faculty of Economics

Department of Finance and Accounting hussam.musa@umb.sk

Ing. Lenka Debnárová, PhD. Matej Bel Univesity in Banská Bystrica Faculty of Economics

Department of Finance and Accounting lenka.debnarova@umb.sk

doc. Ing. Zdenka Musová, PhD. Matej Bel Univesity in Banská Bystrica Faculty of Economics Department of Corporate Economics and Management zdenka.musova@umb.sk

doc. Ing. Peter Krištofík, PhD. Matej Bel Univesity in Banská Bystrica Faculty of Economics Department of Finance and Accounting peter.kristofik@umb.sk 


\begin{tabular}{|c|c|c|c|}
\hline Appendix A: & \multicolumn{3}{|c|}{ Evaluation $1^{\text {st }}, 2^{\text {nd }}$ and $3^{\text {rd }}$ criterion } \\
\hline Criteria & Description & Ordinal scale & $\begin{array}{c}\text { Results - } \\
\text { numbers of } \\
\text { companies } \\
2011 / 2012 / 2013\end{array}$ \\
\hline \multirow{4}{*}{$\begin{array}{l}\text { 1. Disclosure } \\
\text { of information }\end{array}$} & \multirow{4}{*}{$\begin{array}{l}\text { Availability of information to } \\
\text { shareholders and potential } \\
\text { investors. The annual } \\
\text { financial report or annual } \\
\text { report is available in CERI, } \\
\text { in RUZ or on the company's } \\
\text { website. Availability of } \\
\text { information according to } \\
\text { the Act on Stock Exchange } \\
\S 45 \text { in paragraph } 1 \text { and } \\
\text { the Accounting Act } \$ 23 \text { in } \\
\text { paragraph } 2 \text {. }\end{array}$} & $\begin{array}{l}\text { "O" = annual report for the } \\
\text { researched period is not } \\
\text { published in CERI, in RUZ, and } \\
\text { on the company's website either }\end{array}$ & $25 / 25 / 24$ \\
\hline & & $\begin{array}{l}\text { "1“ = annual report is published } \\
\text { in one of the three options } \\
\text { (CERI, RUZ, company's } \\
\text { website) } \\
\end{array}$ & $23 / 8 / 8$ \\
\hline & & $\begin{array}{l}\text { "2" = annual report is published } \\
\text { in two of the three options } \\
\text { (CERI, RUZ, on company" } \\
\text { s website) }\end{array}$ & $56 / 76 / 69$ \\
\hline & & $\begin{array}{l}\text { „3“ = annual report is published } \\
\text { in CERI, in RUZ and also on } \\
\text { company's website }\end{array}$ & $1^{*}$ \\
\hline \multirow{3}{*}{ 2. Annual Report } & \multirow{3}{*}{$\begin{array}{l}\text { The scope and clarity of the } \\
\text { information about corporate } \\
\text { governance in an annual } \\
\text { report. }\end{array}$} & $\begin{array}{l}" 0 "=\text { annual report does not } \\
\text { contain information on corporate } \\
\text { governance }\end{array}$ & $47 / 39 / 53$ \\
\hline & & $\begin{array}{l}1 “=\text { annual report contains } \\
\text { partial information on corporate } \\
\text { governance }\end{array}$ & $43 / 64 / 27$ \\
\hline & & \begin{tabular}{|l|}
$2 "=$ annual report contains \\
partial information on corporate \\
governance and deviations from \\
compliance with the Code
\end{tabular} & $14 / 6 / 22$ \\
\hline \multirow{3}{*}{$\begin{array}{l}\text { 3. Statement } \\
\text { on Corporate } \\
\text { Governance }\end{array}$} & \multirow{3}{*}{$\begin{array}{l}\text { The scope, clarity and } \\
\text { quality of information about } \\
\text { corporate governance } \\
\text { according to the Accounting } \\
\text { Act } \$ 20 \text { in paragraph } 6 \text { a,-g, }\end{array}$} & $\begin{array}{l}" 0 "=\text { the statement is not } \\
\text { available or does not contain } \\
\text { any specific information on CG }\end{array}$ & $57 / 61 / 68$ \\
\hline & & $\begin{array}{l}" 1 "=\text { the statement contains } \\
\text { a brief explanation of each item }\end{array}$ & $40 / 28 / 12$ \\
\hline & & $\begin{array}{l}\text { „2“ = the statement contains an } \\
\text { explanation of each item and } \\
\text { the reason for deviation from } \\
\text { compliance with the Code }\end{array}$ & $7 / 20 / 22$ \\
\hline
\end{tabular}

Source: own

Note: *Disclosure of information in the Register of Financial Statements was observed only in 2013 due to new legislation. 


\begin{tabular}{|c|c|c|c|}
\hline Appendix B: & \multicolumn{3}{|c|}{ Evaluation $4^{\text {th }}, 5^{\text {th }}$ and $6^{\text {th }}$ criterion } \\
\hline Criteria & Description & Ordinal scale & $\begin{array}{c}\text { Results - } \\
\text { numbers of } \\
\text { companies } \\
2011 / 2012 / 2013\end{array}$ \\
\hline \multirow[b]{3}{*}{$\begin{array}{l}\text { 4. Composition } \\
\text { of the boards }\end{array}$} & \multirow{3}{*}{$\begin{array}{l}\text { The scope of information } \\
\text { about board members, such } \\
\text { as names, experience, } \\
\text { responsibilities and } \\
\text { management posts. }\end{array}$} & „0“ - no information & $27 / 31 / 33$ \\
\hline & & $\begin{array}{l}\text { "1“- only the names of board } \\
\text { members }\end{array}$ & $64 / 64 / 57$ \\
\hline & & $\begin{array}{l}2 “ \text { - published the names of } \\
\text { board members, together with } \\
\text { the qualifications, roles and } \\
\text { responsibilities and managerial } \\
\text { posts }\end{array}$ & $13 / 14 / 12$ \\
\hline \multirow{3}{*}{$\begin{array}{l}\text { 5. Remuneration } \\
\text { of boards } \\
\text { members }\end{array}$} & \multirow{3}{*}{$\begin{array}{l}\text { Information about the } \\
\text { structure and amount of } \\
\text { remuneration for individual } \\
\text { members of the board. }\end{array}$} & „0“ = no information & $61 / 63 / 65$ \\
\hline & & \begin{tabular}{|l}
$1 “=$ cumulative data about \\
remuneration for all company's \\
boards that are established
\end{tabular} & $34 / 39 / 32$ \\
\hline & & $\begin{array}{l}\text { "2" = disclosed the amount of } \\
\text { remuneration of board members } \\
\text { and managers of the company } \\
\text { or remuneration disclosed } \\
\text { for individual boards of the } \\
\text { company }\end{array}$ & $9 / 7 / 5$ \\
\hline \multirow{3}{*}{$\begin{array}{l}\text { 6. Information } \\
\text { on risk } \\
\text { management }\end{array}$} & \multirow{3}{*}{$\begin{array}{l}\text { Information on risk } \\
\text { management, defined } \\
\text { predictable risks, monitoring } \\
\text { and quantification of risks. }\end{array}$} & „0“ = no specific information & $72 / 82 / 69$ \\
\hline & & $\begin{array}{l}" 1 "=\text { basic information about } \\
\text { risk management and defined } \\
\text { predictable risks }\end{array}$ & $16 / 10 / 11$ \\
\hline & & $\begin{array}{l}\text { "2“ = comprehensive information } \\
\text { about risk management and risk } \\
\text { quantification }\end{array}$ & $16 / 17 / 22$ \\
\hline
\end{tabular}




\begin{tabular}{|c|c|c|c|}
\hline \multicolumn{4}{|l|}{ Appendix C: } \\
\hline Criteria & Description & Ordinal scale & $\begin{array}{c}\text { Results - } \\
\text { numbers of } \\
\text { companies } \\
2011 / 2012 / 2013 \\
\end{array}$ \\
\hline \multirow{3}{*}{$\begin{array}{l}\text { 7. Audit } \\
\text { Committee }\end{array}$} & \multirow{3}{*}{$\begin{array}{l}\text { Information on whether the } \\
\text { committee was or was not } \\
\text { established, including its } \\
\text { activities. }\end{array}$} & „0“ = no information & $51 / 55 / 50$ \\
\hline & & $\begin{array}{l}\text { "1" = information on whether } \\
\text { the committee was or was not } \\
\text { established (reasons why it was } \\
\text { not established) }\end{array}$ & $34 / 41 / 35$ \\
\hline & & $\begin{array}{l}\text { „2" = is established, } \\
\text { a description of the committee's } \\
\text { and the results of its activities }\end{array}$ & $19 / 13 / 17$ \\
\hline \multirow{3}{*}{$\begin{array}{l}\text { 8. Remuneration } \\
\text { Committee }\end{array}$} & \multirow{3}{*}{$\begin{array}{l}\text { Information on whether the } \\
\text { committee was or was not } \\
\text { established, including its } \\
\text { activities. }\end{array}$} & „0“ = no information & $88 / 87 / 80$ \\
\hline & & $\begin{array}{l}\text { "1" = information on whether } \\
\text { the committee was or was not } \\
\text { established (reasons why it was } \\
\text { not established) }\end{array}$ & $12 / 18 / 17$ \\
\hline & & $\begin{array}{l}\Rightarrow 2 "=\text { is established, } \\
\text { a description of the committee's } \\
\text { and the results of its activities }\end{array}$ & $4 / 4 / 5$ \\
\hline \multirow{3}{*}{$\begin{array}{l}\text { 9. Nomination } \\
\text { Committee }\end{array}$} & \multirow{3}{*}{$\begin{array}{l}\text { Information on whether the } \\
\text { committee was or was not } \\
\text { established, including its } \\
\text { activities. }\end{array}$} & „0“ = no information & $91 / 92 / 85$ \\
\hline & & $\begin{array}{l}\text { "1" = information on whether } \\
\text { the committee was or was not } \\
\text { established (reasons why it was } \\
\text { not established) }\end{array}$ & $12 / 16 / 16$ \\
\hline & & $\begin{array}{l}\text { "2“ = is established, } \\
\text { a description of the committee's } \\
\text { and the results of its activities }\end{array}$ & $1 / 1 / 1$ \\
\hline
\end{tabular}




\section{Abstract}

\section{GENDER EQUALITY AND CORPORATE GOVERNANCE IN SLOVAKIA \\ Hussam Musa, Lenka Debnárová, Zdenka Musová, Peter Krištofík}

Gender representation on company boards is controversial and currently a highly debated issue in corporate governance. It is also considered to be an important tool of corporate responsibility in economic areas. Of all the progressive actions that the EU and Member States have implemented to revive the European economy, the issue of women's participation in the labor market, particularly in corporate governance, merits more attention. Equality between women and men is one of the European Union's founding values yet clearly there are significant differences in pay by gender and representation of women on boards. One of the principles of corporate governance, the responsibilities of the board, is closely related to the issue of gender equality. According to this principle the board should ensure the strategic management of the company, the effective monitoring of management and should act responsibly towards both society and shareholders. These activities may be determined by many factors and one of them is gender equality. Advancing gender equality in the labor market continues to be a policy objective in many European Union countries. Wide national variations are evident in strategies and accomplishments towards improving gender equality at all levels of the labor market, including corporate governance roles. This paper focuses on the effect of gender diversity on corporate governance in companies listed on the Bratislava Stock Exchange. We measured the level of corporate governance by using a corporate governance index, compiled separately by company, and based on information from companies annual reports. The paper uses a correlation analysis to examine the association between the representation of women on boards and the level of corporate governance. To the best of our knowledge, this is the first paper to investigate the link between corporate governance and gender equality in companies on the Bratislava Stock Exchange.

Key Words: Gender policy, gender equality, corporate social responsibility, corporate governance, corporate governance index, Slovakia.

JEL Classification: G34, J16, M14.

DOI: 10.15240/tul/001/2017-1-007 